\title{
Radiation use Efficiency in Rice Crops under Different Numbers of tillers and Nitrogen Fertilizer Applications
}

\author{
Sugiono $^{1,2 *}$, Husni Thamrin Sebayang ${ }^{2}$ and Agus Suryanto ${ }^{2}$
}

\author{
${ }^{1}$ Institute for Agricultural Technology (AIAT) East Java Indonesia \\ ${ }^{2}$ Faculty of Agriculture, Universitas Brawijaya, Malang, East Java, Indonesia \\ *coreesponding: astro_bptp@yahoo.co.id
}

\begin{abstract}
The most important in agricultural activities is the utilization of solar radiation energy, nutrients and water. Plants with enough water and nutrients, Under optimal conditions, nutrition and water are fulfilled, the crop efficient use radiation is determined by the interception of light and the pattern of spread within the plant canopy.Setting number of tillers will affect distribution of radiation in rice. In addition to the radiation use efficiency by setting different number of tillers, nitrogen fertilizer, Urea, is very influential on the growth of plant organs. The aim of the research was to study the effect of different number of tillers and nitrogen fertilizer application on solar conversion energy in rice crops. The research design used a split plot design in which dose of nitrogen fertilizer as the main plot and different number of tillers as subplots. The results showed that urea at doses of 100 and $150 \mathrm{~kg} \mathrm{ha-1}$ was able to provide RUE of 1.37 and 1.39\%, which is higher than 0 and $50 \mathrm{~kg}$ ha-1.Result conversion efficiency treatment number tillers 10 and 15 per plant is 1.34 , increase by $1.37 \%$ compare treatment number tillers 5 per plant.
\end{abstract}

Keyword-lowland rice, nitrogen, number of tillers, radiation use effciency.

\section{INTRODUCTION}

Rice is the most important crops. In Indonesia, rice is the main food commodity to supporting human carbohidrat necessity. Almost the region in Indonesia cultivated rice, especiallythe region that have good irrigation. Plant growth and quality depends on the interaction between environmental factors and plant genetic factors. Genetic factors are related to plant spesific characteristics. In addition to genetic planting factors which are one of the reliable components and a significant contribution in increasing national rice production, climate factors also influence the increase in rice production. According to Suprapto et al. (2013) that interaction between rice and environmental factors affecting the rice growth. In rice cultivation there are still many obstacles in improving rice growth and yield both in terms of nutrients in other management. To improve rice growth by using the right dose of fertilizer. In line with the development and advancement of fertilizer technology and changes in nutrient status in the soil, the existing fertilizer recommendations need to be further examined and refined.

The excessive number of tillers decrease rice yields. The excessive number of tillers indicates that the crop is overmuch fertile during the vegetative phase.
Many Indonesian farmers provide additional fertilizer during the vegetative phase. Indonesian farmers assume that increasing the number of tillers also increase yields. Optimum phase of tillers produced is generally at the age of 50-60 DAP. Setting the number of tillers in a rice family determines the quality of the rice plant family. The quality of rice clumps affect the number of population per unit area and yield. Setting the number of tillers aims to determine the optimum number of tillers.Basically giving the possibility of plants to grow well without competition of taking water, nutrients, and sunlight. Good pattern of cultivation layout is important to optimizing efficiency use radiation of sunlight for photosynthesis.

The aim of this research was to study and determine the radiation use effciency (RUE) in lowland rice by regulating the number of tillers and applying nitrogen fertilizer in the generative phase of rice crops.

\section{MATERIAL AND METHOD}

The experiment was laid in split plot design with three replicate. Factorial experiment consist of 2 treatments, as a main plot is $\mathrm{N}$ (Urea) fertilizer dose from farmers recommendations (N1), $50 \mathrm{~N} \mathrm{~kg}$ ha-1 (N2), 100

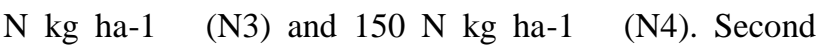
treatment as sub plot is number of tillers consist of 5 
tillers (J5), 10 tillers (J10) and 15 tillers (J15). number of tiller controlling at 45DAP.

Varieties in this research use Inpari-42. Observation before fertilizer application at 50 DAP was used as an initial reference for rice growth. Observations in this experiment consist of 2 parameter, growth and yield parameters. Growth parameter are the number of tillers, leaf area and leaf area index. Yield parameters are yield (harvest) and energy conversion efficiency. In addition, secondary data was collected at the Karangploso $\mathrm{BMKG}$ station to get rainfall intensity and solar radiation data.

Solar energy conversion indicate percentage (\%) of the light energy which is converted into photosynthesis contained in dry matter plants. RUE calculating by different dry weight of plants, at a certain time period by multiplying the coefficient of combustion (4000 cal g-1 ).Results of these calculations then divided by the total intensity of solar radiation in a certain time period which is multiplied by PAR. The RUE calculation formula according to Suprapto et al. (2013).

$$
\mathrm{RUE}=\frac{\Delta \mathrm{W} \cdot \mathrm{K}}{\text { I.t.PAR }} \times 100 \%
$$

The Radiation Use Efficiency (RUE) was described by several components such as difference of plants dry weight $(\Delta \mathrm{W})(\mathrm{g} \mathrm{m}-2)$ in a period $(\mathrm{t})$, Coefficient of burning heat $(\mathrm{K})(4,000 \mathrm{cal} \mathrm{g}-1)$, Intensity of daily radiation (I) (cal $\mathrm{m} 2$ day-1 ), a period of a specific time (day) ( $\mathrm{T}$ ), and photosynthetic Active Radiation (PAR) (0.45). The result data were statistically analyzed using analysis of variance (Anova) to campare the differences between the different treatments.The means were separated by using least significant difference (LSD) test at 5\% and $1 \%$ level of significance.

\section{RESULTS}

The results showed fertiliizer dose and number of tilles have no interaction growth, harvest and energy conversion efficiency parameters. Each treatment showed that the dose of $\mathrm{N}$ fertilizer affected the number of leaves at the age of $65 \mathrm{HST}$, while the treatment of the number of tillers affected the number of leaves at 65 and 80 HST (Table 1).The leaf area index at 65 HST is affected by the number of tillers. J15 leaf area index at the age of 65 HST 1.67 higher than $\mathrm{J} 5$ and $\mathrm{J} 10$, leaf area index respectively 0.94 and 1.27 (Table 2 ).

The yielfd results of harvested in Tables 3 and 4 giving a dose of Nitrogen fertilizer were not significantly different in the components of the Total Dry Weight, Number of Panicles per Clump, Harvest Results, Results, Productive Tiller, Weight 1000 Seeds. But the Spikelet filling percentages $(\%)$ were significantly difference. Number of tillers were significantly affect at parameter Total Dry Weight (g plant-1 ), yield results per plant (g of clump-1 ) and yield (t ha-1 ).

Table 5 shows the use of RUE value of N1 is $1.22 \%$ not significantly different from $\mathrm{N} 2$ which is $1.29 \%$. $\mathrm{N} 1$ is lower than $\mathrm{N} 3$ and N4. The RUE value of N3 is $1.37 \%$, not significantly different from $\mathrm{N} 4$, which is $1.39 \%$. RUE $\mathrm{N} 4$ higher than $\mathrm{N} 1$ and N2. In the treatment of J5 the RUE was $1.24 \%$ lower than that of $\mathrm{J} 10$ and $\mathrm{J} 15$, respectively 1.34 and $1.37 \%$. Whereas RUE J10 and J15 are not significantly different.

Table 1. Effect of Nitrogen Fertilizer Dose and Number of Tillers on Number of Rice Tillers

\begin{tabular}{ccccc}
\hline $\begin{array}{c}\text { Dose N Fertilizer } \\
\left(\mathbf{k g ~ h a}^{-\mathbf{1}}\right)\end{array}$ & \multicolumn{4}{c}{ Number of Tilers on Observation Age (DAT) } \\
\cline { 2 - 5 } $\mathbf{0}$ & $\mathbf{5 0 *}$ & $\mathbf{6 5}$ & $\mathbf{8 0}$ & $\mathbf{9 5}$ \\
\hline $\mathbf{5 0}$ & 26.56 & $12.22 \mathrm{a}$ & 27.25 & 23.25 \\
$\mathbf{1 0 0}$ & 26.44 & $12.88 \mathrm{a}$ & 27.22 & 23.92 \\
$\mathbf{1 5 0}$ & 26.00 & $14.44 \mathrm{~b}$ & 27.95 & 23.92 \\
\hline LSD 5\% & 26.33 & $14.83 \mathrm{~b}$ & 27.12 & 24.25 \\
\hline \multirow{2}{*}{ Number of Tillers } & $\mathrm{ns}$ & 1.07 & $\mathrm{~ns}$ & $\mathrm{~ns}$ \\
\cline { 2 - 5 } & & Number of Tilers on Observation Age (DAT) & $\mathbf{9 5}$ \\
\hline $\mathbf{5}$ & $\mathbf{5 0 *}$ & $\mathbf{6 5}$ & $\mathbf{8 0}$ & 21.44 \\
$\mathbf{1 0}$ & 26.50 & $9.58 \mathrm{a}$ & $26.04 \mathrm{a}$ & 24.69 \\
\hline 15 & 26.50 & $13.33 \mathrm{~b}$ & $28.69 \mathrm{c}$ & 25.38 \\
\hline
\end{tabular}

Note: The numbers in each column and row followed by the same letter are not significantly different at the LSD test level of $5 \%$, DAT: days after transplanting, *: observations before $\mathrm{N}$ fertilizer and number of tillers treatment. ns: non significant. 
Table 2. Effect of nitrogen fertilizer dose and and number of tillers on leaf area index of rice

\begin{tabular}{|c|c|c|c|c|}
\hline \multirow{2}{*}{$\begin{array}{c}\text { Dose N Fertilizer } \\
\left(\mathrm{kg} \mathrm{ha}^{-1}\right)\end{array}$} & \multicolumn{4}{|c|}{ Leaf Area Index on Observation Age (DAT) } \\
\hline & $50 *$ & 65 & 80 & 95 \\
\hline $\mathbf{0}$ & 2.95 & 1.30 & 3.30 & 2.62 \\
\hline 50 & 2.97 & 1.34 & 3.60 & 2.80 \\
\hline 100 & 2.95 & 1.18 & 3.70 & 2.78 \\
\hline 150 & 2.97 & 1.35 & 3.74 & 2.83 \\
\hline LSD $5 \%$ & ns & ns & ns & ns \\
\hline \multirow{2}{*}{ Number of Tillers } & \multicolumn{4}{|c|}{ Leaf Area Index on Observation Age (DAT) } \\
\hline & $50 *$ & 60 & 80 & 95 \\
\hline 5 & 2.98 & $0.94 \mathrm{a}$ & 3.55 & 2.70 \\
\hline 10 & 2.96 & $1.27 \mathrm{a}$ & 3.51 & 2.75 \\
\hline 15 & 2.94 & $1.67 \mathrm{c}$ & 3.70 & 2.82 \\
\hline LSD $5 \%$ & ns & 0.21 & ns & ns \\
\hline
\end{tabular}

Note: The numbers in each column and row followed by the same letter are not significantly different at the LSD test level of $5 \%$, DAT: days after transplanting, *: observations before $\mathrm{N}$ fertilizer and number of tillers treatment. ns: non significant.

Table 3. Effect of nitrogen fertilizer dose and number of tillers on total dry weight, number of panicles per clump and yield

\begin{tabular}{|c|c|c|c|}
\hline \multirow[b]{2}{*}{$\begin{array}{l}\text { Dose N Fertilizer } \\
\qquad\left(\mathrm{kg} \mathrm{ha}^{-1}\right)\end{array}$} & \multicolumn{2}{|r|}{ Harvest Component } & \\
\hline & $\begin{array}{l}\text { Total Dry Weight } \\
\quad\left(\text { g plant }^{-1}\right)\end{array}$ & $\begin{array}{c}\text { Number of panicles per } \\
\text { clump }\end{array}$ & $\begin{array}{l}\text { Yiel per Clump } \\
\quad\left(\text { g clump }^{-1}\right)\end{array}$ \\
\hline $\mathbf{0}$ & 83.96 & 15.78 & 52.96 \\
\hline 50 & 88.13 & 16.20 & 54.15 \\
\hline 100 & 91.40 & 16.98 & 56.89 \\
\hline 150 & 91.06 & 18.01 & 58.30 \\
\hline \multirow[t]{2}{*}{ BNT 5\% } & ns & ns & ns \\
\hline & \multicolumn{3}{|c|}{ Harvest Component } \\
\hline Number of Tillers & $\begin{array}{l}\text { Total Dry Weight } \\
\quad\left(\text { g plant }^{-1}\right)\end{array}$ & $\begin{array}{c}\text { Number of panicles per } \\
\text { clump }\end{array}$ & $\begin{array}{l}\text { Yiel per Clump } \\
\quad\left(\text { g clump }^{-1}\right)\end{array}$ \\
\hline 5 & $85.34 \mathrm{a}$ & 15.88 & $52.36 \mathrm{a}$ \\
\hline 10 & $87.85 \mathrm{ab}$ & 16.47 & $56.01 \mathrm{ab}$ \\
\hline 15 & $92.72 b$ & 17.88 & $58.36 \mathrm{~b}$ \\
\hline LSD $5 \%$ & 5.21 & ns & 4.02 \\
\hline
\end{tabular}

Note: The numbers in each column and row followed by the same letter are not significantly different at the LSD test level of $5 \%$, ns: non significant.

Table 4. Effect of nitrogen fertilizer dose and number of tiller on yield, productive tillers, weight of 1000 seeds and spikelet filling percentages

\begin{tabular}{ccccc}
\hline \multirow{2}{*}{$\begin{array}{c}\text { Dose N Fertilizer } \\
\left(\mathbf{k g ~ h a}^{-\mathbf{1}}\right)\end{array}$} & Yield $\left(\mathbf{t ~ h a}^{-\mathbf{1}}\right)$ & $\begin{array}{c}\text { Hroductive Tillers } \\
(\boldsymbol{\%})\end{array}$ & $\begin{array}{c}\text { Weight of 1000 } \\
\text { seeds }(\mathbf{g})\end{array}$ & $\begin{array}{c}\text { Spikelet filling } \\
\text { percentages }(\boldsymbol{\%})\end{array}$ \\
\cline { 2 - 5 } & $4.37 \mathrm{a}$ & 56.80 & 27.39 & $88.41 \mathrm{c}$ \\
$\mathbf{0}$ & $4.64 \mathrm{a}$ & 56.01 & 27.38 & $87.47 \mathrm{bc}$ \\
$\mathbf{5 0}$ & $4.79 \mathrm{ab}$ & 59.24 & 27.05 & $85.57 \mathrm{a}$ \\
$\mathbf{1 0 0}$ & $5.15 \mathrm{~b}$ & 63.29 & 26.87 & $85.75 \mathrm{ab}$ \\
\hline $\mathbf{1 5 0}$ & 0.47 & $\mathrm{~ns}$ & $\mathrm{~ns}$ & 1.84 \\
\hline LSD 5\% & \multicolumn{4}{c}{ Harvest Component }
\end{tabular}




\begin{tabular}{ccccc} 
& Yield (t ha $\left.\mathbf{~}^{-\mathbf{1}}\right)$ & $\begin{array}{c}\text { Productive Tillers } \\
(\boldsymbol{\%})\end{array}$ & $\begin{array}{c}\text { Productive Tillers } \\
(\boldsymbol{\%})\end{array}$ & Biji Bernas (\%) \\
\hline $\mathbf{5}$ & $4.39 \mathrm{a}$ & 57.35 & 26.81 & 86.76 \\
$\mathbf{1 0}$ & $4.83 \mathrm{~b}$ & 57.29 & 27.18 & 85.76 \\
$\mathbf{1 5}$ & $4.99 \mathrm{~b}$ & 61.88 & 27.52 & 87.89 \\
\hline LSD 5\% & 0.26 & $\mathrm{~ns}$ & $\mathrm{~ns}$ & $\mathrm{~ns}$ \\
\hline
\end{tabular}

Note: The numbers in each column and row followed by the same letter are not significantly different at the LSD test level of $5 \%$, ns: non significant.

Table 5. Effect of nitrogen fertilizer dose and thinning saplings on radiation use efficiency (RUE)

\begin{tabular}{cc}
\hline $\begin{array}{c}\text { Dose N Fertilizer } \\
\left(\mathbf{k g ~ h a}^{-\mathbf{1}}\right)\end{array}$ & RUR (\%) \\
\hline $\mathbf{0}$ & $1.22 \mathrm{a}$ \\
$\mathbf{5 0}$ & $1.29 \mathrm{ab}$ \\
$\mathbf{1 0 0}$ & $1.37 \mathrm{bc}$ \\
$\mathbf{1 5 0}$ & $1.39 \mathrm{c}$ \\
\hline LSD 5\% & 0.13 \\
\hline Number of Tillers & RUE $\mathbf{\%})$ \\
\hline $\mathbf{5}$ & $1.24 \mathrm{a}$ \\
$\mathbf{1 0}$ & $1.34 \mathrm{~b}$ \\
$\mathbf{1 5}$ & $1.37 \mathrm{bc}$ \\
\hline LSD 5\% & 0.09
\end{tabular}

Note: The numbers in each column and row followed by the same letter are not significantly different at the LSD test level of $5 \%$, ns: non significant.

\section{DISCUSSION}

Plant growth parameters showed no interaction between the dose of urea fertilizer and the number of tillers. However, the growth parameters that observed after reducing the tillers per plant (J5,10 and J15) and fertilizing at $50 \mathrm{HST}$ showed that generally affected by the number of tillers and urea fertilizer doses. To produce optimum plant growth and high yields requires the provision of adequate nitrogen supply and population regulation in rice crop (Tabri, 2010). Plant fertilizers at the right dose and in accordance with the needs of plants so that there is a balance of nutrients in the soil that causes plants to grow and develop properly and provide optimal results. In addition, the high number of tillers per plant affects on nutrient competition. Then the low number of tillers affects on less efficient fertilization.

The result after reducing the number of tillers is increase in the number of tillers. After reducing, cutting tillers causes the tillers regrowth. According to Purwanto (2009), the ability to produce tillers affected by genetic, each rice cultivar has different capabilities to produce tillers. However, environmental factors and cultivation affect the number of tillers too. The rate of tiller production stops when the $\mathrm{N}$ content in the leaf blade becomes $2 \%, \mathrm{P} 0.03 \%$ and $\mathrm{K} 0.5 \%$. The rate of tillering increases linearly with increasing $\mathrm{N}$ content to $5 \%, \mathrm{P}$ to
$0.2 \% \mathrm{k}$ to $1.5 \%$ above this value does not affect the formation of tillers. The results showed that no interaction between the dose of urea fertilizer and the number of tillers on Inpari-42. The highest productivity of Inpari-42 is 5.15 tons at $150 \mathrm{~kg} \mathrm{ha}^{-1}$ nitrogen treatment. Schulze and Caldwell (1995) revealed that urea with the appropriate dosage would increase the nitrogen content in the rhizosphere, increase the distribution of nitrogen by compensating and increase the efficient use of nitrogen. Higher urea fertilizer would be toxic to crop then decrease growth and yield. Yield loss is factor that affect the low yield per hectare. Yield loss at the time of harvest solve by several factors, such as harvest age, air content, and tools, and good procedure harvest. In addition, too old age with low water content causes the grain fall off easily during harvest (Lubis et al., 2013).

Higher use of urea fertilizer at the vegetative end phase of the rice plant yields increased results compared to BIJI BERNAS. Increasing nitrogen reduces plant nutrient uptake (Mashur, 2004). When nutrient macros such as $\mathrm{P}$ and $\mathrm{K}$ is inhibited would reduce the quality and quantity of yield. Dobermann and Faithurst (2000) recorded that deficiency $\mathrm{P}$ decreasing yield quality of grain and poor kalium $(\mathrm{K})$ uptake increase the number of empty grain per plant. Higher urea increase the empty grain to reach $19.17 \%$ means the percentage of pithy seeds only reaches $80.83 \%$ (Ambarita et al., 2018). 
The efficient use of solar radiation is the ability of plants to convert energy into biomass. Biomass is a plant's response to the absorption of radiation by the plant canopy. The results showed that RUE in rice crops was affected by the dose of urea fertilizer and the number of tillers. The value of RUE in the study was 1.22 to $1.39 \%$. RUE value of local varieties of rice that is 0.64 to $1.71 \%$ and RUE greatly affect the yield (Zaini et al., ). The research of Ahmad et al. (2009), showed that the RUE values in the two varieties below $2.00 \%$, according to of Lubis et al. (2013) average RUE of 10 rice varieties are of $1.13 \%$, while the research of Varon and Diaz (2015) RUE in rice plants was 1.39 to $1.58 \%$. The value of RUE and the interception of PAR into biomass is also influenced by the population number (Liu et al., 2012), management of care such as fertilization and irrigation (Wang et al., 2015) and the type of variety used (Schneider et al., 2016).

The amount of energy used by canopy affected by plant populations. High population number is negatively affect on growth, grain and yields, due to competitive effects, both on vegetative and reproductive development phase (Ahmad, 2005). Each varieties have different capability to use solar radiaton. Radiation that reaches the plant not be fully utilized, because the responsiveness of plants to radiation. Therefore the efficiency of solar radiation in plants needs to be improved. The greater the amount of energy available will increase the amount of photosynthesis (Zervoudakis et al., 2012).

\section{CONCLUSSION}

$\mathrm{N}$ Fertilizer (Urea) and number of tillers in the rice cultivation affects the growth and yield. Reducing tillers to 5 tillers per clump, it showed a yield of $4.39 \mathrm{t} \mathrm{ha}^{-}$ 1 which was the lowest yield. Giving a very large urea fertilizer reduces the quality of bernas seeds, which is $85.57 \%$. There is urea fertilizer application and regulation of the number of tillers in the efficiency of Inpari-42 rice solar radiation energy conversion. The RUE value obtained is around 1.22 to $1.39 \%$.

\section{REFERENCES}

[1] Ahmad, A., S. Iqbal, S. Ahmad, T. Khaliq, W. Nasim, Z. Husnain, A. Hussain, M. Zia-Ul-Haq and G. Hoogenboom. 2009. Seasonal Growth, Radiation Interception, its Conversion Efficiency and Biomass Production of Oryza Sativa L. under Diverse Agroenvironments in Pakistan. Pak. J. Bot. 41 (3): 1241-1 257.

[2] Ahmad, S., A. Hussain, H. Ali and A. Ahmad. 2005. Transplanted Fine Rice (Oryza sativa L.) Productivity as Affected by Plant Density and Irrigation Regimes. International J. of Agric and Bio. 7(3): 445-447.
[3] Ambarita, Y., D. Hariyono and N. Aini. 2018. The Aplication NPK and Urea on Paddy (Oryza sativa L.) Ratoon System. J. Prod. Tan. 5 (7): 1228-234.

[4] Dobermann, A. and T. Fairhurst. 2000. Rice: nutrient disorders dan nutrient management. IRRI-PPI-PPIC. Canada.

[5] Liu, T.,F. Song., S. Liu., X. Zhu. 2012. Light Interception and Radiation Use Efficiency Response to Narrow-Wide Row Planting Patterns in Maize. Aust. J. of Crop Sci. 6 (3): 506-513.

[6] Lubis, I., M. Ohnisi, K. Katsura and T. Shiraiwa. 2013. Plant Factors Related to Dry Matter Production in Rice Cultivars. J. ISSAAS. 19 (2): 58-67

[7] Mashur, S. 2004. Assessment of Various Doses of Nitrogen Fertilizers Based on Leaf Color Card Scale on Two Varieties of Rice Plants. Proceedings of the 2004 National Technical Functional Meeting of Agriculture. 214-219.

[8] Purwanto. 2009. Growth and Yield of Four Rice Varieties (Oryza sativa L.) in Organic, Semiorganic and Conventional Agriculture Systems. Agronomy Thesis. Gadjah Mada University. Yogyakarata. Hal. 12-1 6.

[9] Schneider, J.R., B.O. Caron, E.F. Elli, F.Schwerz, A.P.Rockenbach, T.D. Engroff. 2016. Conversion efficiency of photosynthetically active radiation in soybean cultivars during planting seasons. Aust. J. Basic Appl. Sci. 10:209-214.

[10] Schulze, E.D., and M.M. Caldwell. 1995. Ecophysiology of photosynthesis ecological studies.Springer link. 100: 576-579

[11] Suprapto, A., Y. Sugito, S.M. Sitompul and Sudaryono. 2013. The Effect of Varieties and Plant Population Densities on Dry Matter Production, Radiation Interception and Radiation Energy Conversion in Peanut. J. Trop. Life Sci. 2 (2): 49- 52.

[12] Tabri, F. 2010. Nitrogen Fertilization Efficiency in Several Corn Varieties in Gowa, South Sulawesi. Proceedings of the National Cereals Week, 2010

[13] Varon, G.G. and H.R. Díaz. 2015. Growth and Yield of Rice Cultivars Sowed on Different Dates under Tropical Conditions. Cien. Inv. Agr. 42(2): 217-226.

[14] Wang, R., T. Cheng, L. Hu. 2015. Effect of wide-narrow row arrangement and plant density on yield and radiation use efficiency of mechanized direct-seeded canola in Central China. Field Crops Res. 172:42-52.

[15] Zaini, A.H., D. Hariyono and K. P. Wicaksono. 2017. Performance of Rice (Oryza Sativa L.) Varieties in Rainy Season and Interaction With Plant Spacing. Bioscience Research. 14(3): 662-667

[16] Zervoudakis, G., G. Salahas, G.Kaspiris and E. Konstantopoulou. 2012. Influence of Light Intensity on Growth and Physiological Characteristics of Common Sage (Salvia officinalis L.). Brazilian Archives of Biol. and Technol. 55 (1): 89-95. 